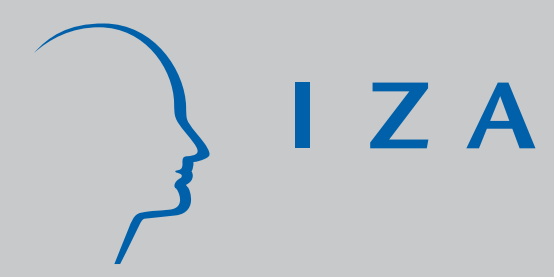

IZA DP No. 1440

The Making of Entrepreneurs in Germany: Are Native Men and Immigrants Alike?

Amelie Constant

Klaus F. Zimmermann

December 2004 


\title{
The Making of Entrepreneurs in Germany: Are Native Men and Immigrants Alike?
}

\author{
Amelie Constant \\ IZA Bonn \\ Klaus F. Zimmermann \\ IZA Bonn, \\ University of Bonn and DIW Berlin \\ Discussion Paper No. 1440 \\ December 2004
}

IZA

P.O. Box 7240

53072 Bonn

Germany

Phone: +49-228-3894-0

Fax: +49-228-3894-180

Email: iza@iza.org

\begin{abstract}
Any opinions expressed here are those of the author(s) and not those of the institute. Research disseminated by IZA may include views on policy, but the institute itself takes no institutional policy positions.

The Institute for the Study of Labor (IZA) in Bonn is a local and virtual international research center and a place of communication between science, politics and business. IZA is an independent nonprofit company supported by Deutsche Post World Net. The center is associated with the University of Bonn and offers a stimulating research environment through its research networks, research support, and visitors and doctoral programs. IZA engages in (i) original and internationally competitive research in all fields of labor economics, (ii) development of policy concepts, and (iii) dissemination of research results and concepts to the interested public.
\end{abstract}

IZA Discussion Papers often represent preliminary work and are circulated to encourage discussion. Citation of such a paper should account for its provisional character. A revised version may be available directly from the author. 


\section{ABSTRACT}

\section{The Making of Entrepreneurs in Germany: Are Native Men and Immigrants Alike?*}

This paper uses a state of the art three-stage technique to identify the characteristics of the self-employed immigrant and native men in Germany and to understand their underlying drive into self-employment. Employing data from the German Socioeconomic Panel 2000 release we find that self-employment is not significantly affected by exposure to Germany or by human capital. But this choice has a very strong intergenerational link and it is also related to homeownership and financial worries. While individuals are strongly pulled into selfemployment if it offers higher earnings, immigrants are additionally pushed into selfemployment when they feel discriminated. Married immigrants are more likely to go into selfemployment, but less likely when they have young children. Immigrants living with foreign passports in ethnic households are more likely self-employed than native Germans. The earnings of self-employed men increase with exposure to Germany, hours worked and occupational prestige; they decrease with high regional unemployment to vacancies ratios. Everything else equal, the earnings of self-employed Germans are not much different from the earnings of the self-employed immigrants, including those who have become German citizens. However, immigrants suffer a strong earnings penalty if they feel discriminated against while they receive a premium if they are German educated.

JEL Classification: J23, M13, J24, J61, J31

Keywords: entrepreneurship, self-employment, occupational choice, immigrants, wage differentials

Corresponding author:

Klaus F. Zimmermann

IZA Bonn

P.O. Box 7240

53072 Bonn

Germany

Email: zimmermann@iza.org

\footnotetext{
* We are grateful for the suggestions of an anonymous referee, which significantly improved the paper. Financial support for this research from Volkswagen Foundation for the IZA project on "The Economics and Persistence of Migrant Ethnicity" is gratefully acknowledged.
} 


\section{Introduction}

Business ownership and self-employment, as an effective form of entrepreneurship, may be a risky venture but it has an intrinsic appeal by offering individuals the sense of independence, of higher self-worth, and life satisfaction. Entrepreneurship not only injects new dynamism into an economy but it is also of great importance for the economic prosperity and the future economic development of a country. Entrepreneurship is also a significant element in combating unemployment and welfare drain through job creation, at the very least for the self-employed themselves. Small entrepreneurs, in particular, have contributed in the creation of revolutionary businesses and they account for the majority of the employed workers.

Although entrepreneurship flourishes in the US and other "immigrants" countries, for any ethnic group, entrepreneurial activities in Germany are comparatively low. Germany is known to have a comparatively low rate of self-employment, but migrants exhibit an even lower rate. This is in spite of the fact that the self-employed immigrants reach earnings parity with self-employed natives and earn a strong premium over immigrant workers in paid-employment. It is unclear why in a country with a relative high unemployment rate and with a relatively institutionalized labor market entry one does not observe more selfemployment among immigrants. Recently, nascent enterprises show that there is a growing business culture in Germany, and they have attracted the government's attention to ensure their boost.

In this paper, we seek to understand whether there are inherent differences in the channel to become self-employed between natives and migrants, or whether the observed differences have more to do with differences in individual characteristics between both groups. We investigate the sources of success measured by earnings in paid-employment and self-employment, and aim to understand potential differences between native Germans and immigrants. We also attempt to deepen our understanding of the effects of ethnicity on entrepreneurship. For that purpose we distinguish ethnic or migrant households (judging from the ethnicity of the household head) from those of the native Germans. And we separately examine the differences to the native Germans for immigrants in German households carrying non German passports, immigrants in ethnic households with German 
passports, and those immigrants in ethnic households that carry other passports.

The paper is structured as follows: In Section 2, we explain the research issues and our methodological approach. Section 3 provides a brief discussion of our data, the variables employed in the analyses, and the underlying hypotheses. In Section 4 we present the econometric evidence and discuss the results of our analyses. We draw our concluding remarks in Section 5.

\section{Research issues and econometric methodology}

In this section, we link our research interest to previous related contributions in the literature, and outline the econometric methodology that we employ in the empirical investigations.

\subsection{Outline of research}

The conjecture of the neoclassical human capital theory is that immigrants are a selfselected group of rational individuals who are willing to undertake risks in order to maximize their lifetime earnings and better their lives. They are characterized by a strong incentive to invest in human capital and have the inner drive to succeed in the host country's labor market. By virtue of their willingness to assume the risk of migration (both pecuniary and psychic) and undertake this new and often risky venture they become the first entrepreneurs. ${ }^{1}$ Put differently, immigrants as risk takers, are more dynamic and inherently more prone to becoming self-employed than any other group. Self-employed individuals are working hard to fulfill their dreams, and in the process they create new jobs and opportunities. On the other hand, impediments to good jobs and to upward occupational mobility as well as unemployment and discrimination in the labor market may impel immigrants to undertake the self-employment avenue. As the literature has shown, entrepreneurship may be the only avenue for their socioeconomic advancement.

While the prevalence of self-employment among both immigrants and natives in the labor market has been researched and documented by many studies in the US, research

\footnotetext{
${ }^{1}$ By definition, an entrepreneur is an individual who organizes, operates, and assumes the risks of a business venture.
} 
on entrepreneurship and especially immigrant entrepreneurship in Europe, and Germany in particular, has been somewhat scant. Recent surveys on the rising literature on selfemployment in a comparative setting investigating research on Europe, the US and other immigration countries include Le (1999), Blanchflower, Oswald and Stutzer (2001), Audretsch (2002), Audretsch, Thurik, Verheul and Wennekers (2002), and van der Sluis, van Praag and Vijverberg (2004). They identify the role of managerial and other individual abilities, family background, occupational status, financial constraints, the nature of work, and ethnic enclaves among other factors as relevant determinants of self-employment.

Van der Sluis, van Praag and Vijverberg (2004) provide a meta-analysis of the empirical research on the impact of schooling on entrepreneurship selection and performance. They find that the schooling effect on self-employment is undetermined while it is positive and significant for earnings. Education affects earnings in Europe stronger for paid employment than for self-employment, but equal or smaller in the US. Blanchflower, Oswald and Stutzer (2001) also study latent entrepreneurship across nations and find that many people would like to be self-employed. However, this preference declines strongly with age and the probability of being self-employed is strongly increasing with age. Selfemployed individuals seem to have a much higher job satisfaction than the employed.

Empirical research on immigrant assimilation has typically found an entry wage disadvantage for immigrants, which narrows over time as immigrants "assimilate" in the host country's labor market. The rate of convergence varies among the different immigrant groups. Borjas' (1986) study on the self-employment experience of immigrants in the US shows that not only self-employed immigrants have higher annual incomes than salaried workers but they also have higher incomes than comparable self-employed natives. This is extended by Lofstrom (2002), who finds substantial differences between migrant workers and self-employed migrants in earnings and educational attainment. Entrepreneurs have a better education and earn more than other working migrants. However, education has a smaller impact on the self-employment probabilities of migrants compared to natives. The earnings of self-employed immigrants converge quickly to the earnings of the self-employed natives.

Evans and Leighton (1989) examine the self-employment decisions of US white 
men. They conclude that self-employment is roughly independent of age and total labor market experience and it is more likely to be undertaken with greater access to assets. Wage experience has been found to have a much smaller return in self-employment than in wage work while experience in business has a similar return in wage work as in selfemployment. Unemployed and low-paid workers are more likely to enter self-employment. Also people who perceive that their performance depends largely on their own actions are more likely to start their own businesses.

In North America, immigrants have higher self-employment rates than natives (see Yuengert, 1995, for the US and Li, 2001, for Canada). Yuengert (1995) investigates the determinants of these differences. He finds that immigrants from countries with larger selfemployment sectors have higher self-employment rates. Migrants in the US cluster more in high-tax states, and find greater opportunities for tax deductions and avoidance as entrepreneurs than as salaried workers. The study is not supportive of the ethnicity enclave hypothesis. Fairlie and Meyer (1996) point out that it is of substantial importance to account for the dramatic ethnic and racial differences in self-employment across the US population. These differences prevail even if one controls for broad combinations of groups such as Asians and Hispanics and the standard tool of regressors. They find that ethnic or racial groups that emigrate from countries with high self-employment rates do not have high selfemployment rates in the US. Their results also suggest that the more economically advanced groups have a higher propensity for self-employment than the more disadvantaged migrant groups.

There is only scarce evidence about migrant entrepreneurs in Europe and especially in Germany. The findings by Clark and Drinkwater (1998) suggest that self-employment is a way out of discrimination in paid-employment for immigrants in Great Britain. Wage work does not pay as well for ethnic minorities, compared to natives, and the wage difference has increased over time. The increase in the earnings disadvantage has been correlated with a rise in the self-employment among ethnic minorities. Although there are higher selfemployment rates for non-whites than for whites, one nevertheless observes a substantive variance among the ethnic groups. Most ethnic minorities also earn less in selfemployment than similar self-employed whites. Borooah and Hart (1999) study the large 
differences in self-employment between Indians and black Caribbean men in Great Britain. They find that social attributes related to family formation are at least as important as individual characteristics. Basu (1998) finds no evidence that Asians in Britain were pushed into self-employment to avoid unemployment. Their economic success as entrepreneurs seems to be positively associated with the share of personal capital invested at the beginning and with educational qualifications.

The immigration process into Germany has been now well studied (see, for instance, Zimmermann, 1995; Constant, 1998). Germany is known to have a comparatively low rate of self-employment, but migrants exhibit an even lower rate. This is in spite of the fact that the self-employed immigrants reach earnings parity with self-employed natives and earn a premium of $30 \%$ over immigrant workers in the blue collar category (Constant, 1998). A recent comparative study between Germany and Denmark shows that the self-employment of immigrants is male dominated and self-employed immigrants in Germany earn twice as much as the immigrants in paid-employment (Constant and Schultz-Nielsen, 2004). It is unclear why in a country with a relative high unemployment rate and with a relatively institutionalized labor market entry one does not observe more self-employment among immigrants. This suggests investigating immigrant entrepreneurship in Germany further.

Therefore, we address the following questions: What factors drive self-employment in Germany among native West Germans and immigrants? Exhibit immigrants at different levels of integration, for instance with foreign passports living in a ethnic or a German household or with a German citizenship living in an immigrant household different work choices? Or is migrant and native German self-employment activity alike when controlled for individual characteristics? How do immigrant entrepreneurs fare in terms of earnings if compared to native Germans and to those in paid employment? To answer these questions we analyze the economic and social determinants of the probability to become an entrepreneur and we estimate earnings regressions that gauge the assimilation effect among the self-employed and those in paid-employment. We control for the standard human capital variables, such as years of education, vocational training, language proficiency, and years of exposure in Germany. Moreover, we add variables to account for labor market characteristics, demographics, social, and psychological ties. 


\subsection{Econometric methodology}

Our methodological framework consists of a 3-stage technique (see Taylor, 1996, Parker, 2003, and Rees and Shah, 1986). Following the literature that men are drawn into selfemployment from the high earnings expectations, we account for the key conjecture that if the expected earnings from self-employment exceed the expected earnings from other types of employment, individual workers (other determinants equal) choose to become selfemployed. While Taylor (1996) finds strong statistical support for this hypothesis, others like Parker (2003) and Rees and Shah (1986) do not. An issue is that the expected relative earnings are not observed and need to be estimated, since we only observe individuals and their earnings in their particular employment states. However, a direct analysis of earnings is potentially misleading since the employment choice per se might affect the estimates through a sample selection bias. To calculate the earnings difference we first need to estimate the correct earnings regressions adjusted for selectivity into self- or paidemployment.

We proceed with the following steps: (I) In the first part of the econometric analysis we investigate a reduced form probit model of the choice behavior of workers. We assume that individual workers are facing two alternatives: the option of becoming self-employed versus the option of being in paid-employment as wage or salary workers. Individual agents maximize utility gained from the attributes of that choice. We assume that utility depends on the corresponding financial rewards of the choice. Such behavior is described in probabilistic terms. We estimate the probability of becoming self-employed based on values of a set of explanatory variables, while our dependent variable is categorical and takes the value of one if an individual is self-employed and the value of zero otherwise.

The explanatory variables (which will be explained in more detail later) consist of a set of human capital variables, individual specific characteristics, socioeconomic characteristics, and industry dummies. We also include variables that measure economic, social, and psychological attachments to Germany, as well as attitudinal variables, feelings

of discrimination, and interaction terms. All these independent variables are expected to affect the individual's probability to become an entrepreneur. The reduced form specification differs from the structural form of the choice because it does not use the 
expected relative earnings from the two occupational choices but industry dummies for identification.

The results from this exercise will provide us insights into the self-selection process to control for a potential sample selection bias in the earnings regressions. Hence, in step (ii) we estimate these earnings regressions for the self- and paid-employed adjusted for selection. We apply the Heckman 2-stage technique using the standard sample selection terms as additional regressors. The dependent variable is the natural logarithm of weekly earnings. To identify earnings we include labor market characteristics and labor market structures. Earnings are a function of the same socioeconomic characteristics for all ethnicity groups with additional variables added to explain the earnings of immigrants (where details are discussed later). The earnings regression results are useful for a couple of reasons: First, to gauge the determinants of monetary success of men in Germany in these two types of employment. Second, to compare the self- to paid-employed by ethnicity. And third, to derive predicted earnings for each type of employment for each individual in the sample that can be used to calculate the difference in expected earnings of the choice between paid-employment and self-employment.

In the last step (iii), we estimate a structural probit on the probability of selfemployment. While this model is similar to the reduced form model, the key identifying variable is the expected earnings difference between the self- and paid-employment states for each individual calculated from the earnings output; and the set of industry dummies used in the reduced form probit model is not included in the structural form. The probability to choose self-employment as opposed to paid-employment is as follows:

$$
P(Y=1)=\alpha+\beta\left(\ln \hat{Y}_{i}^{s e}-\ln \hat{Y}_{i}^{p e}\right)+\gamma X_{i}+\epsilon_{i}
$$

where the term in parenthesis is the difference between the predicted earnings for individual $I$ if he is in self-employment and in paid-employment. The vector $X$ includes the regressors as in the reduced form, excluding the industry dummies. In the following section we explain the variables in vector $X$ in more detail. 


\section{Self-employed and salaried workers in Germany}

In this section, we provide an overview about the basic characteristics of self-employed and salaried workers in Germany by ethnicity. In this analysis, we concentrate on comparing the performance of the migrants with those of the West native Germans and hence exclude East Germans. Even a decade after unification, East Germans do not have significant experiences with self-employment. Migrants still predominantly cluster in West Germany and avoid the less-developed east with the much higher unemployment rates. The group of migrants studied here contains the traditional former "guestworkers," namely those from Greece, Italy, Spain, former Yugoslavia, and Turkey, who or their parents were hired especially in the early sixties to meet a demand for blue collar workers. However, we use also data on the "new" immigrants from the eighties and nineties, who came mainly from Eastern Europe, among them mostly ethnic Germans from Poland, Romania, and states from the former Soviet Union (ex-USSR).

In the following subsections we describe our data source; we explain the creation of the major variables used and outline the basic hypotheses concerning the probability to be self-employed and the determinants of earnings among them; and we present and discuss the major characteristics of the sample populations and highlight the situation of entrepreneurship among natives and migrants in Germany.

\subsection{Data set and construction of our sample}

For the empirical analysis our data are drawn from the German Socioeconomic Panel (GSOEP), a nationally representative data set that has been conducted annually since 1984, provided by the German Institute for Economic Research (DIW Berlin). For our empirical analysis we use data from the GSOEP 2000. This year is unique in that it includes all populations living in Germany augmented by refreshment and innovation samples. It also includes substantial information on labor force participation, self-employment categories, various aspects of life in Germany, and contains an assortment of attitudinal questions. More important, the $\mathbf{2 0 0 0}$ data permit a more detailed analysis of the selfemployed. We can, thus, differentiate between those self-employed in agriculture, in the free-lance or professional sector, and in other self-employed categories including working 
for a family business (SOEP Group, 2001).

Our analysis focuses on the self-employment endeavors of men in Germany in 2000. The samples we select for our analyses exclude those individuals who are enrolled in school, and those in the military, because these groups follow different trajectories. Additionally, we restrict our analysis to individuals who are working and are aged 20 to 64 , a prime age for self-employment endeavors. Lastly, we exclude individuals who had missing answers in key variables. ${ }^{2}$

We construct a dummy for self-employment from a self-reported answer in the GSOEP questionnaire regarding the employment status of the individuals. It includes small and larger scale farming, free-lance processionals, working in other business, and working in family business. For all self-employed, this is their main job. We exclude self-employment as a secondary job. The paid-employment category includes blue collar, white collar, and civil servants. According to our selection criteria we ended up with 5,509 observations of whom 613 are self-employed (or $11.13 \%$ ) and 4,896 are paid-employed.

The dependent variable for the earnings estimation is the natural logarithm of the weekly earnings as reported in the questionnaire.

\subsection{Independent variables and hypotheses}

To capture ethnicity differences in this paper we take advantage of our data set that allows us to differentiate between ethnicity and citizenship. We define the ethnicity of the individual as the ethnicity of the household. Because of the idiosyncrasies of the German migration system and the German immigration law, the typical distinction between first and second generation immigrants does not apply in Germany. Immigrants who are born in Germany are not necessarily considered Germans or have the German citizenship. Often, even if they acquire the German citizenship they are perceived as foreigners and follow separate paths in the labor market. We, thus, distinguish our sample between native German households with 550 self-employed men (or $10 \%$ of the total sample) and 4,036 paid-

${ }^{2}$ To preserve as many individuals as possible, we grouped missing values in some categorical variables in the "other" category; this is either the zero in dummies or the reference group in the categorical variables. For a small number of observations that did not report earnings we imputed values using a Mincerian earnings regression. 
employed men, and other immigrant households with 63 self-employed men (or $1.1 \%$ of the total sample) and 860 paid-employed men. Within the immigrant households we identify 4 different ethnicities of relevant size: (i) ethnic Germans, (ii) ethnic Turks, (iii) ethnic Italians, and (iv) all other immigrants.

We further separate Germans and immigrants by citizenship or passport held. We create a separate category for immigrants who live in German households (either because they are married to Germans or born in Germany) but do not have the German passport. For the immigrants who live in ethnic households we create 4 categories: (i) those who have become German citizens and carry the German passport, (ii) those who have the Turkish passport, (iii) those who have the Italian passport, and (iv) those who have all other types of foreign passports. The reference group in our analysis is naturally the "pure" Germans, that is those who are German citizens and live in German households. This categorization is important in isolating the impact of ethnicity and citizenship on selfemployment proclivity and earnings.

The explanatory variables used in all three stages of the analysis include human capital variables (exposure to Germany, pre- and post-migration education, German language proficiency, and health), familial controls (marital status and young children), ethnicity and citizenship controls, regional economic situation (regional unemployment to vacancies ratio), and discrimination variables. Specifically, we create the variable exposure that measures the time and quality of exposure to the German environment as well as labor market experience accumulated in Germany. For Germans, this variable is the same as age. For immigrants born in Germany exposure equals their age; for those migrating later in life exposure equals the reported years they have accumulated in Germany; and for those with missing values in the year of arrival we carefully calculated the exposure variable following a simple algorithm: if the individual is born elsewhere but went to school in Germany we assigned years of migration according to whether the individual went to elementary or secondary school in Germany. While older workers are more risk averse, we expect that self-employment proclivity will increase with age discounted for non-linearities. Older workers have more wisdom, more experience and know-how, more financial capital, larger social milieu, and they make more prudent choices. There is also a strong concave 
relationship between earnings and age.

For Germans, we create a variable for their years of formal schooling and vocational training. For immigrants, we measure the effects of years of schooling and vocational training in the home country and years of schooling and vocational training in Germany separately. That way we control for differences in the initial stock of human capital (education before migration) and render immigrants' education in Germany qualitatively similar to that of Germans and among themselves. We enter the schooling variables in a non-linear form to capture increasing or decreasing returns to schooling. To the extent that education captures higher ability and allows individuals to know more and to have superior information set, we would expect that more years of schooling will push individuals into selfemployment. In Germany, we would expect a strong correlation between education and self-employment because, especially for certain occupations, there are required educational requirements and qualifications. However, it has been often argued that selfemployment is an alternative job choice for less qualified and less skilled individuals.

Health is a vital element of human capital. We include the variable "healthy" constructed from questions on personal and official evaluation of their health. We hypothesize that disability and self-employment are negatively correlated. Marital status plays a role in self-employment from two conflicting directions. On the one hand, marriage brings stability and, married men, it has been shown, are more productive through the division of labor and household production. Self-employment can also be a very attractive choice for married individuals because it can offer flexibility in the allocation of time between family and work. Moreover, married men can benefit from their wife's support and can count on her helping with their business as well. Self-employed married men, can also count on their wife's stable income, if she is working, as an income smoothing to go through rough times strategy. However, this is a more plausible scenario for immigrants and certain occupations. On the other hand, self-employment is considered as a risky venture and as such married men might not opt for this choice, especially when their household depends on their income.

Immigrants were also asked about whether they feel discriminated against in Germany. From their answers we create 2 variables for whether they feel totally or seldom 
discriminated; not feel discriminated at all is the omitted category. This is an important variable to capture the push theory of self-employment. For many individuals, especially minorities self-employment may be a forced choice, meaning that they cannot find another job due to discrimination. If this is so, then they should fare very well as self-employed. Another reason why individuals are pushed into self-employment is the fact that they cannot find a job due to high unemployment rates. During periods of high unemployment individuals may want to open their own business rather than staying idle. ${ }^{3}$ To test this hypothesis we create a variable of the regional male unemployment over the regional vacancies using information from the German Statistical Yearbook (Statistisches Bundesamt, 2002).

In sum we conjecture that: (i) both the probability to self-employment and earnings from self-employment increase with age and exposure to Germany at a decreasing rate, (ii) more educated and healthier individuals will have a higher probability to go into selfemployment and higher earnings once they are self-employed, (iii) married men with children will have a higher probability to go into self-employment and earn more, (iv) there are significant differences between Germans and immigrants in both the self-employment probability and in earnings, and ( $v$ ) discrimination and high unemployment to vacancies ratios push individuals into self-employment.

In both the reduced form probit and the earnings selection regression we include an additional important identifier of the labor market, industry categories. The omitted group is agriculture, mining and other not reported answers. These variables will help us derive more accurate estimated earnings for the self- and paid-employed. The reduced form probit of the probability of self-employment is identified by whether the parents are self-employed, the individuals own their home, they face the future with optimism and confidence, and they have financial worries. For immigrants, we include their willingness to stay in Germany. We interact the "non immigrant" variables with being an immigrant and add as additional controls. This probit model, then, produces the selection term $\lambda$ that is important in adjusting the mean of earnings. A positive and significant $\lambda$ indicates that self-employed

${ }^{3}$ While the chances of survival and success are lower during this period, the decision to go into self-employment stands. 
men are not a random sample of workers but positively self-selected.

In the earnings regression we include the language information for immigrants (speaking mostly German). The variable "speak mostly German" is derived from a selfreported answer. Immigrants were asked whether they speak mostly German in their everyday life. While it does not necessarily reflect superior knowledge of the language, it nonetheless captures the easiness immigrants have with the German language, and the image they portray to the others about being willing to integrate. Speaking the host country's language facilitates economic adaptation and improves economic performance. Self-employment is in most cases customer intensive and people oriented. We expect that those who speak mostly German will have higher earnings than those who do not.

The following identifiers of earnings pertain to the labor market structures: hours per week working, Treiman occupational prestige scores, tenure/seniority with a job/business, working with a small or large company. We expect that those self-employed men who work longer hours, and whose business is in a higher ranked prestige scale will enjoy higher earnings. Having a more stable business - captured by the variable length of time with business - reflects a serious commitment in the labor market and should have a direct advantage in earnings. Working in or owning a large company should also provide an earnings premium compared to working in or owning an average company. We lastly include interaction terms of all non immigrant variables with immigrant ethnicity. These interactions will show us whether Germans and immigrants have different earnings in relation to specific attributes.

The most important part of this study is the estimation of the structural probit. The crucial identifier of this regression is the estimated difference between the predicted earnings of self- and paid-employment. This is to test the hypothesis that rational individuals choose self-employment based on the higher earnings that it can offer. The literature has often shown that men are pulled into self-employment for monetary reasons. We also include variables that show intergenerational spillovers (parents are selfemployed), socioeconomic attachments to Germany and to the country of origin (citizenship, own a dwelling in Germany, and want to stay in Germany), and other attitudinal (optimism about the future, financial worries) and control variables (regional unemployment 
to vacancies ratio).

We expect individuals with self-employed parents to have a significantly higher probability of self-employment. Parents besides acting as role models, can also provide know-how and free on-the-job training. Children of self-employed parents have the advantage of inheriting the business and have an established clientele. We hypothesize that there is a strong positive link between self-employed parents and children. The variable homeownership is included as proxy for the individual's wealth. We expect that wealth will increase the probability of self-employment because it lessens the liquidity constraints (Taylor, 1996; Evans and Leighton, 1989). Further, we expect that those individuals who worry about finances will have a higher probability to go into self-employment lured by the higher expected financial rewards from self-employment. Individuals who have a positive attitude towards the future and express confidence and optimism will be more likely to go into self-employment.

Lastly, we hypothesize that immigrants who want to stay in Germany will also choose more likely self-employment as a means of becoming successful and have a business to hand down to their children. The interactions of the non immigrant variables with ethnicity will provide us with better insights on the differences between immigrants and natives on their probability to self-employment.

\subsection{Characteristics of the sample populations}

The differences in labor force participation and earnings between self-employed and salaried workers in our sample by ethnicity are highlighted in Table 1. Self-employed native Germans occupy $10 \%$ of the sample while all self-employed immigrants make up only $1.1 \%$ of the sample. Within the self-employed group, almost $90 \%$ are native Germans and $10 \%$ are immigrants. Among the $10 \%$ immigrants in the self-employment group, the immigrants from all other groups together score a high percentage (4\%), while we observe that it is the ethnic Germans who have the next highest share (2.4\%) followed by the Turks $(2.1 \%)$ and the Italians $(1.5 \%)$ indicating that they are quite entrepreneurial. Only $1.5 \%$ of the immigrant self-employed sample are Italians. However, even more interesting are the differences in the self-employment rates among the various groups: Compared to Germans (12.0\%), who 
are known to exhibit a low entrepreneurial activity, immigrants have an even much lower average self-employment rate (6.6\%). Among the ethnic groups studied here, Italians have the highest self-employment rate $(8.7 \%)$ followed by ethnic others $(6.9 \%)$, and ethnic Germans (6.0\%), while ethnic Turks rank last (5.5\%).

\section{$<<$ Table 1 about here $>>$}

With regards to their earnings, we find that for all groups the self-employed earn a lot more than the paid-employed. For example, the native Germans who are in paidemployment earn $23 \%$ less that their self-employed counterparts and all paid-employed immigrants earn on average $40 \%$ less than immigrants in self-employment. Within the immigrant ethnicities, the most remarkable contrast between self- and paid-employed is with Turks. Turks in paid employment earn $42 \%$ less than their self-employed counterparts. It is clear form this table that self-employment offers men a lucrative job. It is noteworthy that self-employed immigrants earn $7 \%$ more than self-employed native Germans, and selfemployed ethnic Germans have the highest weekly earnings among all immigrants. These statistics show that not only self-employment is a remunerative choice for all men but for immigrants, in particular, self-employment is a means of traversing and even annihilating the native-ethnic wage disparity.

In Table 2 we repeat this contrast between self- and paid-employed for men in Germany according to their citizenship status. The reference group is men with German passports living in native German households. Immigrants who live in German households but do not have the German passport have the highest share among all migrant groups (3.6\%), followed by migrants with other passports (3.3\%), those with Turkish passport $(1.8 \%)$, those with Italian passport (1.6\%), and immigrants in non-German households with German passport (1.5\%). Germans (living in German households) with German passport have the highest self-employment rate among all groups $(12.1 \%)$, followed by the immigrants living in German households (with non-German passports) who have a rate of $9.1 \%$. Among the immigrants living not in German households, those with Italian passport rank first $(9.5 \%)$, followed by other passports $(8.9 \%)$, and Turkish and German passports 
(5.9\%). Among the workers in paid-employment, men with German passports living in native German households have a lower share (80.2\%) than among the self-employed (88.2\%). Immigrants with German passports living in German households represent 7.2\% among the paid-employed people, and $1.5 \%$ among the self-employed.

\section{$<<$ Table 2 about here $>>$}

The lower bottom of Table 2 shows that self-employed Germans and immigrants earn more than their paid-employed counterparts. The earnings disparity between self-end paid-employment is the lowest for the native Germans $(23 \%)$ and the highest for immigrants in German households who do not have the German passport (48\%). This reflects the fact that the latter are thriving in self-employment. Not only they earn more than similar workers in paid-employment but they earn the highest among all citizenship groups, even more than the native Germans. While the self-employed men with Turkish passport earn, on average, more than their paid-employed counterparts ( $39 \%$ disparity) they earn $24 \%$ less than immigrants with a German passport.

In Table 3, we portray citizenship versus national identity and integration issues. With regards to the immigrant population in Germany, the GSOEP gives us the opportunity to look at their citizenship, their multiple nationalities, and the country they are born in. Here we compare self- to paid-employed men by ethnicity, that is German versus immigrant households. Ninety eight percent of self-employed individuals in German households are German citizens, and $97 \%$ of them have been born in the German territory. Only $35 \%$ of the self-employed individuals in immigrant households are German citizens while $64 \%$ of them have been born in Germany. Immigrants who want to maintain their cultural and ethnic identities are often blamed as causing conflict within the host country and their poor performance is often explained through their desire to maintain their identities. The summary statistics on the citizenship, nationality, feelings of belonging in Germany and desire to stay in Germany show that these characteristics vary by employment status. A lower percentage of the self-employed men in immigrant households are German citizens, compared to paid-employed immigrants. Among the self-employed non German citizens 
in immigrant households, $24 \%$ are born in Germany but have their parents' nationality. ${ }^{4}$ Interestingly enough, the self-employed non German citizens in immigrant households have higher intentions to apply for citizenship than the salaried workers. Whereas more of them would apply for citizenship if they were allowed to keep their parents' citizenship, still, fewer self-employed men would opt for that.

$<<$ Table 3 about here >>

An interesting fact from this table is that a lower percentage of the self-employed immigrants, whether in a German or other household, feels comfortable in Germany and wants to stay in Germany compared to the salaried workers. This alludes to the fact that immigrants are pushed into self-employment. However, when they were asked whether they feel totally discriminated, a smaller fraction among the self-employed immigrants said yes than the paid-employed.

Table 3 shows that the self-employed men, irrespective of their ethnicity are clearly more optimistic and see the future with higher confidence, compared to the paid-employed. A higher percentage of the self-employed are also homeowners and in good health than the paid-employed. Individuals with self-employed parents clearly choose self-employment themselves, no matter the ethnicity. With regards to worries, more self-employed men express worries about their financial situation (than the paid-employed) but fewer selfemployed men worry about their job compared to paid-employed. Also, fewer selfemployed men worry about immigration to Germany than the paid-employed do. Lastly, while the self-employed in German households are not as concerned about hostility against immigrants in Germany as the paid-employed are, the self-employed in immigrant households seem to be very concerned about hostility against immigrants in Germany.

Table A1 in the Appendix shows the types of self-employment our samples are in.

\footnotetext{
${ }^{4}$ Up until recently citizenship in Germany was synonymous to nationality and was based on the "law of blood." Accordingly, individuals born outside Germany are Germans if their ancestry is German. The new law combines the existing law of blood with the "law of soil" that is the law in the US, for example. Individuals born in Germany are Germans but they have to decide by the age of 18 which nationality to keep. Naturalization rates increased by $130 \%$ in 2000 mainly due to the decreased time limit.
} 
Overall, the majority of self-employed men (whether Germans or immigrants) own smallscale businesses of less than nine employees. Almost twice as many Germans than immigrants are in the self-employed farmer category. The vast majority of self-employed men irrespective of nationality lies in the "other business" category. This category includes retail and restaurants. Immigrants dominate this category, especially in the small scale business $(76 \%)$. About $23 \%$ of the Germans are in the free-lance professional category but only $14 \%$ of the immigrants. This category includes lawyers, doctors, teachers, and the hitech computer category. On the other hand, we find more immigrants than Germans working in the family business. This indicates that immigrants rely more on kinship and familial support when they open a new business.

\section{Estimation results}

In the tables of this section we present the results of our empirical investigations. We provide the coefficient estimates with the standard errors in parenthesis underneath. One asterisk denotes the significance level at $5 \%$ in a two-tail test. We concentrate our analysis of the findings on these significant results. ${ }^{5}$

\subsection{Reduced form Probit on the probability of self-employment}

Table 4 contains the results of the (reduced form) binomial probit regression estimation of the probability of self-employment. Note that these findings give some insights in the selection process into self-employment, but the major contribution of the reduced form probit model is to generate the appropriate sub-samples for estimating the earnings equations for the self-employed and the paid-employed workers. The probability to become self-employed increases significantly with exposure to Germany, but at a decreasing rate.

Surprisingly, education is not a significant determinant of the self-employment propensity. One explanation could be that the years of schooling between self-employed and salaried Germans are the same.

${ }^{5}$ The means and standard deviations of all variables used in the analyses are provided in the Appendix, Table A2. 
$<<$ Table 4 about here >>

Individuals in good health and men with young children are more likely to go into self-employment. However, marriage is a deterrent to entrepreneurship for men in Germany. According to theory and empirical results for other countries, women subsidize their husbands' jobs. That is, men rely on their wives for a steady income if they work outside of the family business and count on their helping directly in the business. We believe that this result can be explained by the more traditional - in the sense of the "breadwinner" ideology - German family. That is, women in Germany have a long tradition of staying home and taking care of the children and the household and rely on their husbands to provide for the household. Consequently, self-employment, which can be a risky venture, would not be an optimal choice for men.

We find a very strong intergenerational link for self-employment as we find that homeownership and financial worries increase the probability of self-employment. Compared to workers in agriculture and mining, those in the manufacturing and government industries are less likely to go into self-employment. Lastly, none of the immigrant related variables are significant in the probability of self-employment.

\subsection{Selection adjusted earnings results}

In Table 5 we present the results of the selection adjusted earnings regressions for selfemployed and paid-employed men. Starting with the earnings of the self-employed, we find that the exposure-earnings profile is concave for the natives and U-shaped for the migrants. Education does not have a significant effect on the earnings of the self-employed natives. While more education makes individuals more capable and well-rounded the stereotypical returns to education scenario for the paid-employment does not apply here. However, the expected positive (and concave) effect of education in line with the metaresearch findings of van der Sluis, van Praag and Vijverberg (2004) show up for the migrants.

$<<$ Table 5 about here >> 
Immigrants who feel that they are discriminated against suffer a devastating penalty. Ethnic Germans earn less than native West Germans, and those immigrants who speak mostly German earn $31 \%$ more than those who do not speak German. All self-employed men enjoy higher earnings when they work more hours and have higher prestige occupational scores. As expected, earnings also decrease by $3.3 \%$ for those who live in areas with high unemployment over vacancies ratio. Compared to those in agriculture or mining, workers in service, retail, construction, and financial industries earn 26 to $65 \%$ more. The selection term indicates that there is positive selection into self-employment and that self-employed workers are not a random sample of all workers.

We now turn to the earnings of the paid-employed. Comparing this column to the self-employed, we see that the intercept is higher for the paid-employed indicating that the self-employed start at lower levels. However, they reach a higher mean of log weekly wages showing that the earnings potential in self-employment is high. The earnings of the paid-employed increase with age or exposure to Germany at a decreasing rate, with education in Germany and good health. Married men and men with young children enjoy a premium of about $8 \%$, together of about $16 \%$.

The immigrants who speak German also earn $5 \%$ more than those who do not. In comparison to native West German men, immigrants earn $22 \%$ more, and those among them who have kept their passport earn $7 \%$ more. In general, length of time with the company, more hours of work and higher prestige scores also lead to an increase in the earnings of men. However, earnings decrease when individuals live in areas with a high unemployment to vacancies ratio. As expected, workers in small companies earn less and workers in large companies earn more than workers in average size companies.

Turning to the industry dummies, we observe that workers in manufacturing, construction, and financial industries earn more than those in the agricultural or mining sectors. The interaction terms with immigrants show that the earnings of immigrants increase with additional years in Germany at a decreasing rate. For the paid-employed we cannot confirm any selection, since the respective estimate is not significant.

All in all, there are some differences between the earnings of natives and migrants in the self-employed and paid-employed category. However, the differences do not come 
so much from differences in the effect parameters of the same characteristics, but are due to different constants between migrants and natives and additional variables describing the particular behavior of migrants.

\subsection{Structural Probit on the probability of self-employment}

In Table 6 we present the findings of the most important step of our econometric investigation, the structural probit model. We also provide the marginal effects. Having self-employed parents exerts a positive impact on the probability of self-employment. In fact, those men whose parents are self-employed are ten PERCENT?times more likely to become self-employed than others whose parents are not self-employed. The probability to become self-employed also increases with homeownership. Among immigrants, those who have kept their passport are more likely to become self-employed compared to native West Germans. Definitely, immigrants are pushed into self-employment if they feel discriminated against; they are 46 PERCENT?times more likely to go into self-employment compared to those who do not feel discriminated at all.

$$
<<\text { Table } 6 \text { about here >> }
$$

Another strong and positive determinant of self-employment is financial worries. Men who have financial worries are 7 PERCENT?times more likely to go into self-employment, indicating that they hope for better economic rewards in self-employment. The earnings difference between the expected self- and paid-employment definitely plays a catalytic role in the probability of self-employment. The larger the difference is, the higher the probability is. Lastly, immigrant men who are married are more likely to go into self-employment while those with young children are less likely.

Compared to the findings of the reduced form probit approach, the structural probit model exhibits a number of differences. Most notably, the distinctions between the migrants and the natives are much more marked. In particular, the role of family, the feelings of discrimination and citizenship become relevant determinants of the self-employment choice. 
As a consequence, the making of entrepreneurs is very much alike between native Germans and migrants. The relevant joint factors are a positive income perspective, financial concerns, homeownership and the experience with self-employed parents provide a positive drive. Given the same individual characteristics, native men and foreigners do exhibit the same probability of self-employment. Differences arise from strong feelings of the migrants to be discriminated, a positive effect of their marital status and a negative effect from the existence of small kids. Immigrants who do not live in German households but still carry their foreign passport are more likely self-employed than natives.

\section{Conclusions}

In this paper we initiated the analysis of the entrepreneurial behavior and monetary success of men in Germany. In particular, we estimated the earnings of the self-employed and paidemployed to identify the determinants of their success. Based on the predicted earnings difference between self- and paid-employment we estimated the probability of individual men choosing self-employment as opposed to salaried jobs. We employed a 3-stage econometric estimation process applied on the 2000 data from the German Socioeconomic Panel (GSOEP).

We find that, unlike other immigrant countries (for example the US with a booming entrepreneurial sector and where immigrant entrepreneurship flourishes), Germany's selfemployment sector occupies a very low percentage. While $12 \%$ of the German men are self-employed, only $6.6 \%$ of the immigrant male labor force exhibit entrepreneurial activities. Summary statistics show that self-employed men earn a lot more than their paidemployed counterparts, supporting the presumption that men are drown into selfemployment lured by the higher earnings that it offers. The smallest contrast between selfand paid-employment earnings is observed for native Germans and the highest for ethnic Turks. The contrast for the other immigrant groups is in between. This shows that selfemployment is more beneficial for immigrants than for natives. However, in addition to the monetary lure immigrants are pushed into self-employment due to the discrimination they feel it exists against them.

The empirical results presented in this paper suggest that, Germans and immigrants 
are drawn into the world of business ownership largely by the same motives. Overall, the probability of self-employment increases significantly for those workers whose parents are self-employed, who are homeowners, and worry about financial matters. Immigrants who feel discriminated against also have a substantially higher probability to go into selfemployment. Marriage and children are significant determinants for self-employment for immigrants only. While married immigrant men are more likely to choose the selfemployment avenue, those who have young children are less likely to choose the selfemployment avenue. Lastly, a higher difference between self- and paid-employment earnings strongly and significantly increases the probability of self-employment.

Our human capital earnings regression analysis (adjusted for selection into both types of employment) revealed that the years of exposure to Germany are a crucial determinant of earnings for both types of employment, and have a concave relationship. In general, for either type of employment, men in Germany earn more when they work more hours, have a higher Treiman occupational prestige score, and work in construction or banking industry. Controlling for everything else, men who live in areas with high unemployment to vacancies ratios suffer a high earnings penalty. For immigrants, earnings increase significantly when they speak mostly German, indicating a powerful effect of language. However, their earnings decrease with additional years in Germany in a non linear way, which also might indicate cohort effects.

All in all, there are some differences between the earnings of natives and migrants in the self-employed and paid-employed category. However, the differences do not come so much from differences in the effect parameters of the same characteristics, but are due to different constants between migrants and natives and additional variables describing the particular behavior of migrants. Specifically for the earnings of the self-employed we find that there are no discernible differences between Germans and immigrants in our sample. The exception is the ethnic Germans who actually earn less than the native Germans. The self-employed immigrants who feel that they are discriminated against also earn less. Those who are German schooled, however, earn more. 


\section{References}

Audretsch, David B., 2002, Entrepreneurship: A Survey of the Literature, paper prepared for the European Commission, Enterprise Directorate General, mimeo.

Audretsch, David B., Roy Thurik, Ingrid Verheul and Sander Wennekers, 2002, Entrepreneurship: Determinants and Policy in a European-U.S. Comparison, Boston: Kluwer Academic Publishers.

Basu, Anuradha, 1998, "An Exploration of Entrepreneurial Activity among Asian Small Businesses in Britain”, Small Business Economics 10 (4), 313-326.

Blanchflower, David G., Andrew Oswald and Alois Stutzer, 2001, "Latent Entrepreneurship Across Nations", European Economic Review 45, 680-691.

Borooah, Vani K. and Mark Hart, 1999, "Factors Affecting Self-Employment among Indian and Black Caribbean Men in Britain", Small Business Economics 13 (2), 111-129.

Borjas, George J., 1986, "The Self-Employment Experience of Immigrants", Journal of Human Resources 21 (4), 485-506.

Clark, Kenneth and Stephen Drinkwater, 1998, "Ethnicity and Self-employment in Britain", Oxford Bulletin of Economics and Statistics 60 (3), 383-407.

Constant, Amelie, 1998, The Earnings of Male and Female Guestworkers and Their Assimilation into the German Labor Market: A Panel Study 1984-1993, Ph.D. Dissertation: Vanderbilt University.

Constant, Amelie and Marie-Louise Schultz-Nielsen, 2004, "Immigrant Self-employment and Economic Performance", in Migrants, Work, and the Welfare State, Tranæs, T. and. Zimmermann, K. F., editors. University Press of Southern Denmark: Odense.

Evans, David S. and Linda S. Leighton, 1989, "Some Empirical Aspects of Entrepreneurship", American Economic Review 79 (3), 519-535.

Fairlie, Robert W. and Bruce D. Meyer, 1996, "Ethnic and Racial Self-employment Differences and Possible Explanations", Journal of Human Resources 31 (4), 757-793.

Le, Anh T., 1999, "Empirical Studies of Self-Employment", Journal of Economic Surveys 13 (4), 381-416.

Li, Peter S., 2001, “Immigrants' Propensity to Self-employment: Evidence from Canada”, International Migration Review 35, 1106-1128.

Lofstrom, Magnus, 2002, "Labor Market Assimilation and the Self-employment Decision of 
Immigrant Entrepreneurs", Journal of Population Economics 15, 83-114.

Parker, Simon C., 2003, "Does Tax Evasion Affect Occupational Choice?", Oxford Bulletin of Economics and Statistics 65 (3), 379-394.

Rees, Hedley and Anup Shah, 1986, "An Empirical Analysis of Self-Employment in the U.K.", Journal of Applied Econometrics 1 (1), 95-108.

SOEP Group, 2001, "The German Socio-Economic Panel (GSOEP) after more than 15 years - Overview", Quarterly Journal of Economic Research 70, 7-14.

Statistisches Bundesamt, 2002, Statistisches Jahrbuch 2002, Wiesbaden: Statistisches Bundesamt.

Taylor, Mark P., 1996, "Earnings, Independence or Unemployment: Why Become SelfEmployed?", Oxford Bulletin of Economics and Statistics 58 (3), 253-266.

Van der Sluis, Justin, C. Mirjam van Praag, and Wim Vijverberg, 2004, Entrepreneurship Selection and Performance: A Meta-analysis of the Impact of Education in Industrialized Countries, Tinbergen Institute Working Paper No. TI 03-046/3.

Veall, Michael R., and Klaus F. Zimmermann, 1992, "Pseudo- ${ }^{21}$ in the Ordinal Probit Model", Journal of Mathematical Sociology, 16, 333-342.

Yuengert, Andrew M., 1995, "Testing Hypotheses of Immigrant Self-Employment", Journal of Human Resources 30 (1), 194-204.

Zimmermann, Klaus F., 1995, "Tackling the European Migration Problem", Journal of Economic Perspectives 9, 45-62. 
TABLE 1. LABOR FORCE PARTICIPATION AND EARNINGS ON SELF-EMPLOYED AND SALARIED WORKERS BY ETHNICITY ${ }^{1}$

\begin{tabular}{cccccc}
\hline & \multicolumn{3}{c}{ Self-employed } & \multicolumn{2}{c}{ Paid-employed } \\
\cline { 2 - 6 } Labor Force Participation (in \%) & $\begin{array}{c}\text { \% of self- } \\
\text { employed }\end{array}$ & $\begin{array}{c}\text { \% of total } \\
\text { sample }\end{array}$ & $\begin{array}{c}\text { \% of } \\
\text { group }\end{array}$ & $\begin{array}{c}\text { \% of paid- } \\
\text { employed }\end{array}$ & $\begin{array}{c}\text { \% of total } \\
\text { sample }\end{array}$ \\
\hline Native Germans & 89.7 & 10.0 & 12.0 & 82.4 & 73.3 \\
All Immigrants (non German households) & 10.3 & 1.1 & 6.6 & 17.6 & 15.6 \\
Ethnic Germans & 2.4 & 0.3 & 6.0 & 5.3 & 4.7 \\
Ethnic Turks & 2.1 & 0.2 & 5.5 & 3.8 & 3.4 \\
Ethnic Italians & 1.5 & 0.2 & 8.7 & 2.4 & 2.1 \\
Ethnic Others & 4.3 & 0.4 & 6.9 & 6.1 & 5.4
\end{tabular}

Weekly Earnings

Native Germans

$1,648.49$

$1,266.36$

All Immigrants (non German households)

$1,768.40$

$1,069.93$

Ethnic Germans

$1,885.48$

$1,118.17$

Ethnic Turks

$1,686.10$

987.19

Ethnic Italians

$1,770.81$

$1,047.85$

Ethnic Others

$1,740.73$

$1,089.01$

Average earnings for all groups

$1,660.81$

$1,231.86$

Number of observations

Self-employed as \% of total sample

11.13

Note: ${ }^{1}$ Ethnicity of the individual is defined as ethnicity of the household Source: Own calculations from GSOEP 2000 
TABLE 2. LABOR FORCE PARTICIPATION AND EARNINGS ON SELF-EMPLOYED AND SALARIED WORKERS BY CITIZENSHIP

\begin{tabular}{|c|c|c|c|c|c|}
\hline \multirow[b]{2}{*}{ Labor Force Participation (in \%) } & \multicolumn{3}{|c|}{ Self-employed } & \multicolumn{2}{|c|}{ Paid-employed } \\
\hline & $\begin{array}{l}\text { \% of self- } \\
\text { employed }\end{array}$ & $\begin{array}{c}\% \text { of total } \\
\text { sample }\end{array}$ & $\begin{array}{l}\% \text { of } \\
\text { group }\end{array}$ & $\begin{array}{l}\% \text { of paid- } \\
\text { employed }\end{array}$ & $\begin{array}{c}\% \text { of total } \\
\text { sample }\end{array}$ \\
\hline $\begin{array}{l}\text { Men from native German households with } \\
\text { German passport }\end{array}$ & 88.2 & 9.8 & 12.1 & 80.2 & 71.2 \\
\hline $\begin{array}{l}\text { Immigrants in German households with Non } \\
\text { German passport }\end{array}$ & 3.6 & 0.2 & 9.1 & 2.2 & 2.0 \\
\hline \multicolumn{6}{|l|}{ Immigrants not in German households } \\
\hline With German passport & 1.5 & 0.4 & 5.9 & 7.2 & 6.4 \\
\hline With Turkish passport & 1.8 & 0.2 & 5.9 & 3.6 & 3.2 \\
\hline With Italian passport & 1.6 & 0.2 & 9.5 & 2.2 & 1.9 \\
\hline With other passports ${ }^{1}$ & 3.3 & 0.4 & 8.9 & 4.6 & 4.1 \\
\hline \multicolumn{6}{|l|}{ Weekly Earnings } \\
\hline Native Germans with German passport & \multirow{2}{*}{\multicolumn{3}{|c|}{$\begin{array}{l}1,640.71 \\
2,116.14\end{array}$}} & \multicolumn{2}{|c|}{$1,271.04$} \\
\hline $\begin{array}{l}\text { Immigrants in German households with Non } \\
\text { German passport }\end{array}$ & & & & \multicolumn{2}{|c|}{$1,097.66$} \\
\hline \multicolumn{6}{|l|}{ Immigrants not in German households } \\
\hline With German passport & \multicolumn{3}{|c|}{$2,056.52$} & \multicolumn{2}{|c|}{$1,126.27$} \\
\hline With Turkish passport & \multicolumn{3}{|c|}{$1,570.89$} & \multicolumn{2}{|c|}{963.60} \\
\hline With Italian passport & \multicolumn{3}{|c|}{$1,941.09$} & \multicolumn{2}{|c|}{$1,021.05$} \\
\hline With other passports ${ }^{1}$ & \multicolumn{3}{|c|}{$1,228.50$} & \multicolumn{2}{|c|}{$1,084.84$} \\
\hline Number of observations & \multicolumn{3}{|c|}{613} & \multicolumn{2}{|c|}{4,896} \\
\hline Self-employed as $\%$ of total sample & & 11.13 & & \multicolumn{2}{|c|}{ - } \\
\hline
\end{tabular}

Note: ${ }^{1}$ Includes Spanish, ex-Yugoslav, Greek, and other passports Source: Own calculations from GSOEP 2000 
TABLE 3. SELECTED CHARACTERISTICS ON CITIZENSHIP AND ATTITUDINAL VARIABLES BY EMPLOYMENT STATUS AND ETHNICITY

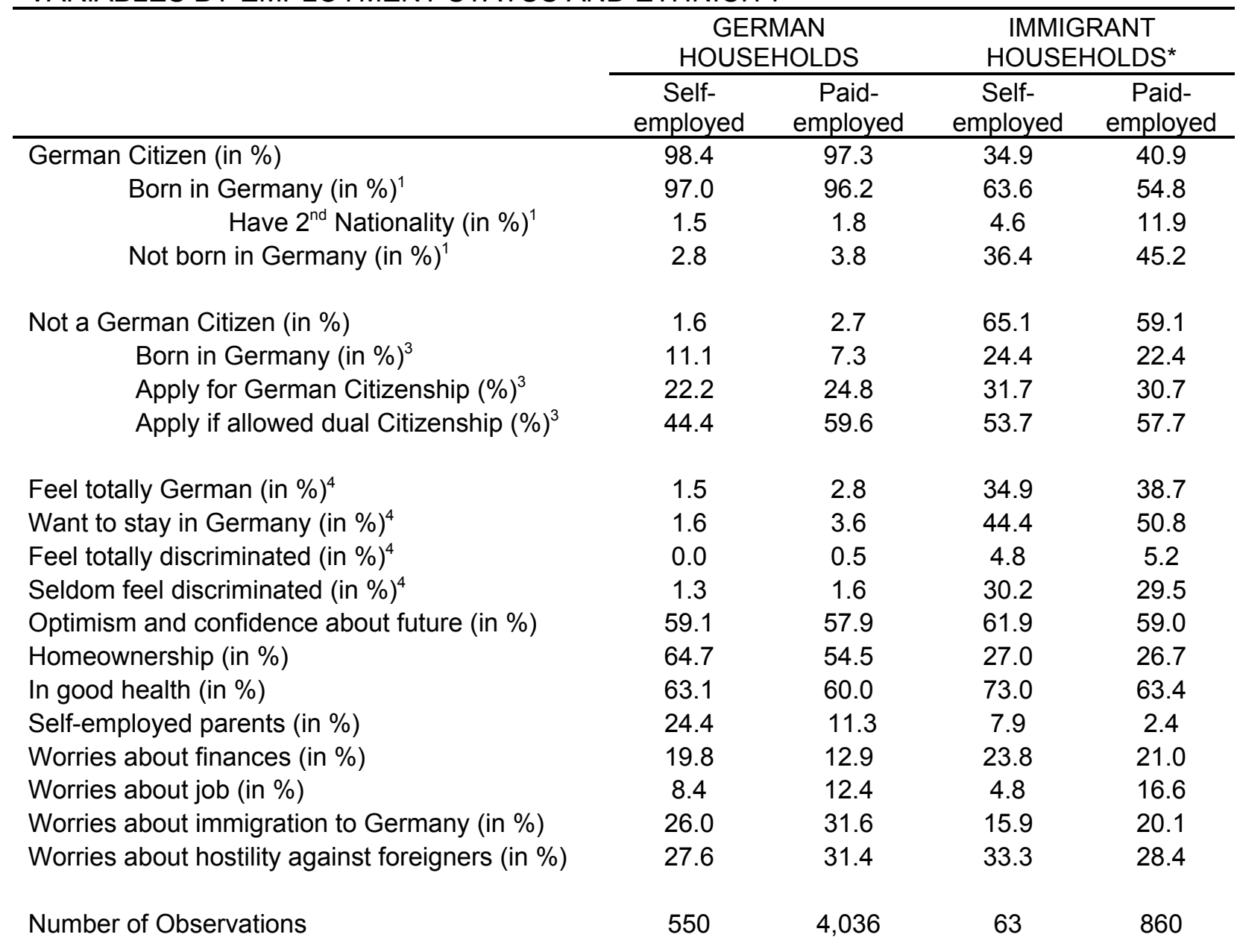

Note: * Includes Greeks, Italians, Spaniards, ex-Yugoslavs, ethnic Germans, and other Eastern Europeans

${ }^{1}$ Based on the German Citizens

${ }^{2}$ Based on the German Citizens who are not born in Germany

${ }^{3}$ Based on the NON German Citizens

${ }^{4}$ Asked only immigrants

Source: Own calculations from GSOEP 2000 
TABLE 4. REDUCED FORM PROBIT ESTIMATION RESULTS: PROBABILITY OF SELFEMPLOYMENT

\begin{tabular}{lc}
\hline Parameters & Coefficient \\
& $($ St. Error) \\
\hline Constant & $-2.578^{*}$ \\
& $(0.449)$ \\
Exposure to Germany & $0.035^{*}$ \\
Exposure to Germany squared & $(0.016)$ \\
Education in Germany & $-0.0002^{*}$ \\
& $(0.0002)$ \\
Education in Germany squared & 0.033 \\
& $(0.050)$ \\
Education before migration & -0.0002 \\
& $(0.002)$ \\
Education before migration squared & 0.057 \\
In good health & $(0.067)$ \\
Married & 0.002 \\
Young children & $(0.005)$ \\
Self-employed parents & $0.126^{*}$ \\
& $(0.058)$ \\
Homeowners & $-0.180^{*}$ \\
& $(0.073)$ \\
All immigrants & $0.156^{*}$ \\
Ethnic Germans & $(0.065)$ \\
Immigrants in German households with Non German & $0.503^{*}$ \\
passport & $(0.068)$ \\
Immigrants not in German households with German & $0.155^{*}$ \\
passport & $(0.058)$ \\
Immigrants not in German households with other & 0.118 \\
passports & $(0.581)$ \\
Feel totally discriminated & -0.018 \\
Seldom feel discriminated & $(0.216)$ \\
& -0.107 \\
Optimism and confidence about future & $(0.239)$ \\
Want to stay in Germany & -0.218 \\
Financial worries & $(0.229)$ \\
Service, other industry & -0.009 \\
& $(0.221)$ \\
-0.200 \\
$(0.329)$ \\
0.206 \\
$(0.150)$ \\
0.047 \\
& $(0.057)$ \\
0.110 \\
& $(0.268)$ \\
$0.353^{*}$ \\
$(0.072)$ \\
-0.164 \\
\end{tabular}




\section{TABLE 4. REDUCED FORM PROBIT ESTIMATION RESULTS: PROBABILITY OF SELF-}

EMPLOYMENT

\begin{tabular}{|c|c|}
\hline & (0.117) \\
\hline Retail, wholesale, trade & $\begin{array}{l}-0.095 \\
(0.120)\end{array}$ \\
\hline Government & $\begin{array}{l}-1.087^{*} \\
(0.128)\end{array}$ \\
\hline Manufacturing & $\begin{array}{l}-0.984^{*} \\
(0.115)\end{array}$ \\
\hline Construction & $\begin{array}{l}-0.143 \\
(0.118)\end{array}$ \\
\hline Financial, Banking industry & $\begin{array}{c}0.037 \\
(0.118)\end{array}$ \\
\hline Regional Unemployment-Vacancies ratio & $\begin{array}{l}-0.005 \\
(0.010)\end{array}$ \\
\hline Immigrants * exposure to Germany & $\begin{array}{l}-0.012 \\
(0.027)\end{array}$ \\
\hline Immigrants * exposure to Germany squared & $\begin{array}{l}0.00003 \\
(0.0004)\end{array}$ \\
\hline Immigrants * education in Germany & $\begin{array}{c}0.044 \\
(0.057)\end{array}$ \\
\hline Immigrants * education in Germany squared & $\begin{array}{l}-0.002 \\
(0.003)\end{array}$ \\
\hline Immigrants * Regional Unemployment-Vacancies ratio & $\begin{array}{c}0.011 \\
(0.029)\end{array}$ \\
\hline Immigrants * married & $\begin{array}{c}0.292 \\
(0.201)\end{array}$ \\
\hline Immigrants * young children & $\begin{array}{l}-0.254 \\
(0.170)\end{array}$ \\
\hline Immigrants * good health & $\begin{array}{c}0.175 \\
(0.174)\end{array}$ \\
\hline Immigrants * homeownership & $\begin{array}{c}-0.117 \\
(0.170)\end{array}$ \\
\hline Immigrants * optimism & $\begin{array}{c}0.089 \\
(0.160)\end{array}$ \\
\hline Immigrants * stay in Germany & $\begin{array}{c}-0.273 \\
(0.313)\end{array}$ \\
\hline Immigrants * financial worries & $\begin{array}{l}-0.174 \\
(0.189)\end{array}$ \\
\hline Immigrants * self-employed parents & $\begin{array}{c}0.113 \\
(0.315)\end{array}$ \\
\hline $\begin{array}{l}\chi^{2} \text { value } \\
\text { Log-Likelihood value } \\
\text { Veall / Zimmermann Pseudo }-\mathrm{R}^{2} \\
\text { Number of observations }\end{array}$ & $\begin{array}{c}558.44 \\
-1,644.35 \\
0.22 \\
5,509\end{array}$ \\
\hline
\end{tabular}


TABLE 5. SELECTION ADJUSTED EARNINGS REGRESSIONS

\begin{tabular}{|c|c|c|}
\hline & SELF-EMPLOYED & PAID-EMPLOYED \\
\hline Parameters & $\begin{array}{c}\text { Coefficient } \\
\text { (St. Error) }\end{array}$ & $\begin{array}{l}\text { Coefficient } \\
\text { (St. Error) }\end{array}$ \\
\hline Constant & $\begin{array}{l}4.413^{*} \\
(0.515)\end{array}$ & $\begin{array}{l}4.645^{*} \\
(0.079)\end{array}$ \\
\hline Exposure to Germany & $\begin{array}{l}0.050^{*} \\
(0.015)\end{array}$ & $\begin{array}{l}0.029^{*} \\
(0.003)\end{array}$ \\
\hline Exposure to Germany squared & $\begin{array}{l}-0.0004^{*} \\
(0.0002)\end{array}$ & $\begin{array}{l}-0.0003^{*} \\
(0.00003)\end{array}$ \\
\hline Education in Germany & $\begin{array}{l}-0.047 \\
(0.048)\end{array}$ & $\begin{array}{l}-0.003 \\
(0.009)\end{array}$ \\
\hline Education in Germany squared & $\begin{array}{c}0.002 \\
(0.002)\end{array}$ & $\begin{array}{c}0.001^{*} \\
(0.0003)\end{array}$ \\
\hline Education before migration & $\begin{array}{c}0.086 \\
(0.062)\end{array}$ & $\begin{array}{c}0.016 \\
(0.013)\end{array}$ \\
\hline Education before migration squared & $\begin{array}{l}-0.003 \\
(0.005)\end{array}$ & $\begin{array}{c}0.001 \\
(0.001)\end{array}$ \\
\hline In good health & $\begin{array}{c}0.077 \\
(0.050)\end{array}$ & $\begin{array}{l}0.050^{*} \\
(0.011)\end{array}$ \\
\hline Speak mostly German & $\begin{array}{l}0.312^{* *} \\
(0.165)\end{array}$ & $\begin{array}{l}0.049^{*} \\
(0.023)\end{array}$ \\
\hline Married & $\begin{array}{c}0.006 \\
(0.064)\end{array}$ & $\begin{array}{l}0.076^{*} \\
(0.015)\end{array}$ \\
\hline Young children & $\begin{array}{c}0.077 \\
(0.061)\end{array}$ & $\begin{array}{l}0.078^{*} \\
(0.013)\end{array}$ \\
\hline All immigrants & $\begin{array}{c}0.699 \\
(0.534)\end{array}$ & $\begin{array}{l}0.217^{*} \\
(0.085)\end{array}$ \\
\hline Ethnic Germans & $\begin{array}{c}-0.372^{\star *} \\
(0.212)\end{array}$ & $\begin{array}{l}-0.030 \\
(0.036)\end{array}$ \\
\hline $\begin{array}{l}\text { Immigrants in German households with Non } \\
\text { German passport }\end{array}$ & $\begin{array}{l}-0.001 \\
(0.252)\end{array}$ & $\begin{array}{l}-0.007 \\
(0.039)\end{array}$ \\
\hline $\begin{array}{l}\text { Immigrants not in German households with } \\
\text { German passport }\end{array}$ & $\begin{array}{c}0.121 \\
(0.231)\end{array}$ & $\begin{array}{c}0.024 \\
(0.036)\end{array}$ \\
\hline $\begin{array}{l}\text { Immigrants not in German households with other } \\
\text { passports }\end{array}$ & $\begin{array}{l}-0.327 \\
(0.224)\end{array}$ & $\begin{array}{l}0.068^{* *} \\
(0.039)\end{array}$ \\
\hline Feel totally discriminated & $\begin{array}{l}-1.468^{*} \\
(0.376)\end{array}$ & $\begin{array}{l}-0.049 \\
(0.045)\end{array}$ \\
\hline Seldom feel discriminated & $\begin{array}{c}0.014 \\
(0.153)\end{array}$ & $\begin{array}{c}0.010 \\
(0.024)\end{array}$ \\
\hline Weekly hours & $\begin{array}{l}0.013^{*} \\
(0.002)\end{array}$ & $\begin{array}{l}0.021^{*} \\
(0.001)\end{array}$ \\
\hline Length of time with firm & $\begin{array}{c}0.004 \\
(0.003)\end{array}$ & $\begin{array}{l}0.011^{*} \\
(0.001)\end{array}$ \\
\hline Treiman prestige score & $\begin{array}{l}0.012^{*} \\
(0.002)\end{array}$ & $\begin{array}{l}0.011^{*} \\
(0.001)\end{array}$ \\
\hline Regional Unemployment-Vacancies ratio & $\begin{array}{l}-0.033^{*} \\
(0.009)\end{array}$ & $\begin{array}{l}-0.014^{*} \\
(0.002)\end{array}$ \\
\hline Work in small company & $\begin{array}{l}-0.168 \\
(0.108)\end{array}$ & $\begin{array}{l}-0.108^{*} \\
(0.014)\end{array}$ \\
\hline Work in large company & -0.257 & $0.096^{*}$ \\
\hline
\end{tabular}




\begin{tabular}{|c|c|c|}
\hline & $(0.177)$ & $(0.011)$ \\
\hline Service, other industry & $\begin{array}{l}0.255^{*} \\
(0.100)\end{array}$ & $\begin{array}{l}-0.004 \\
(0.030)\end{array}$ \\
\hline Retail, wholesale, trade & $\begin{array}{l}0.385^{*} \\
(0.098)\end{array}$ & $\begin{array}{c}0.049 \\
(0.031)\end{array}$ \\
\hline Government & $\begin{array}{c}0.219 \\
(0.168)\end{array}$ & $\begin{array}{l}-0.035 \\
(0.035)\end{array}$ \\
\hline Manufacturing & $\begin{array}{l}0.115 \\
(0.140)\end{array}$ & $\begin{array}{l}0.160^{*} \\
(0.033)\end{array}$ \\
\hline Construction & $\begin{array}{l}0.554^{*} \\
(0.098)\end{array}$ & $\begin{array}{l}0.149^{*} \\
(0.030)\end{array}$ \\
\hline Financial, Banking industry & $\begin{array}{l}0.646^{*} \\
(0.096)\end{array}$ & $\begin{array}{l}0.205^{*} \\
(0.031)\end{array}$ \\
\hline Immigrants * exposure to Germany & $\begin{array}{l}-0.066^{*} \\
(0.026)\end{array}$ & $\begin{array}{l}-0.016^{*} \\
(0.005)\end{array}$ \\
\hline Immigrants * exposure to Germany squared & $\begin{array}{c}0.001^{*} \\
(0.0004)\end{array}$ & $\begin{array}{l}0.0001^{* *} \\
(0.0001)\end{array}$ \\
\hline Immigrants * education in Germany & $\begin{array}{l}0.146^{*} \\
(0.055)\end{array}$ & $\begin{array}{c}0.013 \\
(0.010)\end{array}$ \\
\hline Immigrants * education in Germany squared & $\begin{array}{c}-0.005^{* *} \\
(0.003)\end{array}$ & $\begin{array}{l}0.0001 \\
(0.001)\end{array}$ \\
\hline $\begin{array}{l}\text { Immigrants * Regional Unemployment-Vacancies } \\
\text { ratio }\end{array}$ & $\begin{array}{l}-0.015 \\
(0.028)\end{array}$ & $\begin{array}{c}0.002 \\
(0.005)\end{array}$ \\
\hline Immigrants * married & $\begin{array}{l}-0.219 \\
(0.223)\end{array}$ & $\begin{array}{l}-0.022 \\
(0.034)\end{array}$ \\
\hline Immigrants * young children & $\begin{array}{l}0.150 \\
(0.187)\end{array}$ & $\begin{array}{c}0.020 \\
(0.029)\end{array}$ \\
\hline Immigrants * good health & $\begin{array}{l}0.156 \\
(0.183)\end{array}$ & $\begin{array}{l}-0.007 \\
(0.027)\end{array}$ \\
\hline$\lambda$ & $\begin{array}{l}0.217^{\star \star} \\
(0.116)\end{array}$ & $\begin{array}{c}0.020 \\
(0.065)\end{array}$ \\
\hline $\begin{array}{l}\text { Log weekly earnings } \\
\text { (st. dev) }\end{array}$ & $\begin{array}{l}7.217 \\
(0.666)\end{array}$ & $\begin{array}{l}7.008 \\
(0.497)\end{array}$ \\
\hline Log-Likelihood value & -455.21 & $-1,536.80$ \\
\hline $\mathrm{R}^{2}$ & 0.377 & 0.552 \\
\hline F-test & $F[38,574]=9.14$ & $F[38,4857]=157.49$ \\
\hline Number of observations & 613 & 4,896 \\
\hline
\end{tabular}


TABLE 6. STRUCTURAL PROBIT ESTIMATION RESULTS: PROBABILITY OF SELFEMPLOYMENT

\begin{tabular}{|c|c|c|}
\hline Parameters & $\begin{array}{l}\text { Coefficient } \\
\text { (St. Error) })^{1}\end{array}$ & $\begin{array}{l}\text { Marginal Effects } \\
\text { (St. Error) }\end{array}$ \\
\hline Constant & $\begin{array}{l}-2.437^{*} \\
(0.470)\end{array}$ & $\begin{array}{l}-0.386^{*} \\
(0.073)\end{array}$ \\
\hline Exposure to Germany & $\begin{array}{c}0.025 \\
(0.018)\end{array}$ & $\begin{array}{c}0.004 \\
(0.003)\end{array}$ \\
\hline Exposure to Germany squared & $\begin{array}{l}-0.0002 \\
(0.0002)\end{array}$ & $\begin{array}{l}-0.00003 \\
(0.00003)\end{array}$ \\
\hline Education in Germany & $\begin{array}{l}0.065 \\
(0.049)\end{array}$ & $\begin{array}{c}0.010 \\
(0.008)\end{array}$ \\
\hline Education in Germany squared & $\begin{array}{l}-0.001 \\
(0.002)\end{array}$ & $\begin{array}{l}-0.0002 \\
(0.0003)\end{array}$ \\
\hline Education before migration & $\begin{array}{l}-0.014 \\
(0.063)\end{array}$ & $\begin{array}{l}-0.002 \\
(0.010)\end{array}$ \\
\hline Education before migration squared & $\begin{array}{l}0.005 \\
(0.005)\end{array}$ & $\begin{array}{c}0.001 \\
(0.001)\end{array}$ \\
\hline In good health & $\begin{array}{c}0.099 \\
(0.056)\end{array}$ & $\begin{array}{l}0.015^{* *} \\
(0.009)\end{array}$ \\
\hline Married & $\begin{array}{l}-0.041 \\
(0.074)\end{array}$ & $\begin{array}{l}-0.007 \\
(0.012)\end{array}$ \\
\hline Young children & $\begin{array}{c}0.119 \\
(0.063)\end{array}$ & $\begin{array}{l}0.019^{\star *} \\
(0.010)\end{array}$ \\
\hline Self-employed parents & $\begin{array}{l}0.500^{*} \\
(0.067)\end{array}$ & $\begin{array}{l}0.102^{*} \\
(0.017)\end{array}$ \\
\hline Homeowners & $\begin{array}{l}0.156^{*} \\
(0.055)\end{array}$ & $\begin{array}{l}0.025^{\star} \\
(0.009)\end{array}$ \\
\hline All immigrants & $\begin{array}{l}-0.410 \\
(0.648)\end{array}$ & $\begin{array}{l}-0.054 \\
(0.070)\end{array}$ \\
\hline Ethnic Germans & $\begin{array}{c}0.351 \\
(0.223)\end{array}$ & $\begin{array}{l}0.068 \\
(0.051)\end{array}$ \\
\hline $\begin{array}{l}\text { Immigrants in German households with Non } \\
\text { German passport }\end{array}$ & $\begin{array}{l}-0.207 \\
(0.243)\end{array}$ & $\begin{array}{l}-0.029 \\
(0.029)\end{array}$ \\
\hline $\begin{array}{l}\text { Immigrants not in German households with } \\
\text { German passport }\end{array}$ & $\begin{array}{l}-0.302 \\
(0.230)\end{array}$ & $\begin{array}{l}-0.040 \\
(0.025)\end{array}$ \\
\hline $\begin{array}{l}\text { Immigrants not in German households with other } \\
\text { passports }\end{array}$ & $\begin{array}{l}0.455^{*} \\
(0.228)\end{array}$ & $\begin{array}{c}0.095 \\
(0.060)\end{array}$ \\
\hline Feel totally discriminated & $\begin{array}{l}1.497^{*} \\
(0.331)\end{array}$ & $\begin{array}{l}0.463^{*} \\
(0.130)\end{array}$ \\
\hline Seldom feel discriminated & $\begin{array}{l}0.208 \\
(0.148)\end{array}$ & $\begin{array}{c}0.037 \\
(0.029)\end{array}$ \\
\hline Optimism and confidence about future & $\begin{array}{c}0.042 \\
(0.055)\end{array}$ & $\begin{array}{l}0.007 \\
(0.009)\end{array}$ \\
\hline Want to stay in Germany & $\begin{array}{l}-0.119 \\
(0.290)\end{array}$ & $\begin{array}{l}-0.018 \\
(0.040)\end{array}$ \\
\hline Financial worries & $\begin{array}{l}0.384^{*} \\
(0.071)\end{array}$ & $\begin{array}{l}0.073^{*} \\
(0.016)\end{array}$ \\
\hline Regional Unemployment-Vacancies ratio & $\begin{array}{c}0.017 \\
(0.010)\end{array}$ & $\begin{array}{l}0.003^{* *} \\
(0.002)\end{array}$ \\
\hline Earnings difference & $1.187^{*}$ & $0.188^{*}$ \\
\hline
\end{tabular}


TABLE 6. STRUCTURAL PROBIT ESTIMATION RESULTS: PROBABILITY OF SELFEMPLOYMENT

\begin{tabular}{|c|c|c|}
\hline & $(0.077)$ & $(0.012)$ \\
\hline Immigrants * exposure to Germany & $\begin{array}{c}0.032 \\
(0.030)\end{array}$ & $\begin{array}{c}0.005 \\
(0.005)\end{array}$ \\
\hline Immigrants * exposure to Germany squared & $\begin{array}{l}-0.001 \\
(0.001)\end{array}$ & $\begin{array}{r}-0.0001 \\
(0.0001)\end{array}$ \\
\hline Immigrants * education in Germany & $\begin{array}{l}-0.084 \\
(0.058)\end{array}$ & $\begin{array}{l}-0.013 \\
(0.009)\end{array}$ \\
\hline Immigrants * education in Germany squared & $\begin{array}{l}0.003 \\
(0.003)\end{array}$ & $\begin{array}{l}0.001 \\
(0.001)\end{array}$ \\
\hline $\begin{array}{l}\text { Immigrants * Regional Unemployment-Vacancies } \\
\text { ratio }\end{array}$ & $\begin{array}{c}0.031 \\
(0.029)\end{array}$ & $\begin{array}{c}0.005 \\
(0.005)\end{array}$ \\
\hline Immigrants * married & $\begin{array}{l}0.539^{*} \\
(0.194)\end{array}$ & $\begin{array}{l}0.110^{*} \\
(0.049)\end{array}$ \\
\hline Immigrants * young children & $\begin{array}{l}-0.416^{*} \\
(0.157)\end{array}$ & $\begin{array}{l}-0.052^{*} \\
(0.015)\end{array}$ \\
\hline Immigrants * good health & $\begin{array}{l}-0.049 \\
(0.155)\end{array}$ & $\begin{array}{l}-0.008 \\
(0.023)\end{array}$ \\
\hline Immigrants * homeownership & $\begin{array}{l}-0.121 \\
(0.168)\end{array}$ & $\begin{array}{l}-0.018 \\
(0.023)\end{array}$ \\
\hline Immigrants * optimism & $\begin{array}{c}0.035 \\
(0.153)\end{array}$ & $\begin{array}{l}0.006 \\
(0.025)\end{array}$ \\
\hline Immigrants * stay in Germany & $\begin{array}{l}-0.107 \\
(0.332)\end{array}$ & $\begin{array}{l}-0.016 \\
(0.046)\end{array}$ \\
\hline Immigrants * financial worries & $\begin{array}{l}-0.246 \\
(0.176)\end{array}$ & $\begin{array}{l}-0.033^{* *} \\
(0.020)\end{array}$ \\
\hline Immigrants * self-employed parents & $\begin{array}{l}0.126 \\
(0.345)\end{array}$ & $\begin{array}{c}0.022 \\
(0.064)\end{array}$ \\
\hline $\begin{array}{l}\chi^{2} \text { value } \\
\text { Log-Likelihood value } \\
\text { Veall / Zimmermann Pseudo }-\mathrm{R}^{2} \\
\text { Number of observations }\end{array}$ & \multirow{2}{*}{\multicolumn{2}{|c|}{$\begin{array}{c}395.257 \\
-1,725.93 \\
0.163 \\
5,509\end{array}$}} \\
\hline $\begin{array}{l}\text { Note: }{ }^{1} \text { These are robust standard errors } \\
{ }^{*} p<0.05 \\
{ }^{* *} P<0.10\end{array}$ & & \\
\hline
\end{tabular}




\section{APPENDIX}

TABLE A1. TYPE OF SELF-EMPLOYMENT BY ETHNICITY

SELF-EMPLOYED
GERMAN
HOUSEHOLDS

SELF-EMPLOYED

ALL IMMIGRANT

\begin{tabular}{|c|c|c|}
\hline Independent Farmer & & \\
\hline with $<9$ co-workers & 6.55 & 3.18 \\
\hline Free-Lance Professional & & \\
\hline with $<9$ employees & 23.46 & 14.28 \\
\hline with $>=9$ employees & 2.0 & 1.59 \\
\hline Other Business & & \\
\hline with $<9$ employees & 60.36 & 76.19 \\
\hline with $>=9$ employees & 6.55 & 3.17 \\
\hline Work in Family Business & 1.09 & 1.59 \\
\hline Number of Observations & 550 & 63 \\
\hline
\end{tabular}


TABLE A2. SUMMARY STATISTICS OF ALL VARIABLES IN ANALYSES

\begin{tabular}{|c|c|c|}
\hline Parameters & Means & St. Deviation \\
\hline All Self-employed & 0.111 & 0.314 \\
\hline All Paid-employed & 0.889 & 0.314 \\
\hline Exposure to Germany & 37.810 & 13.159 \\
\hline Education in Germany & 11.578 & 4.432 \\
\hline Education before Migration ${ }^{1}$ & 0.913 & 2.667 \\
\hline In good health & 0.610 & 0.488 \\
\hline Speak mostly German ${ }^{1}$ & 0.070 & 0.255 \\
\hline Married & 0.717 & 0.450 \\
\hline Young children & 0.442 & 0.497 \\
\hline Self-employed parents & 0.112 & 0.316 \\
\hline Homeowners & 0.509 & 0.500 \\
\hline All immigrants ${ }^{1}$ & 0.168 & 0.373 \\
\hline Ethnic Germans ${ }^{1}$ & 0.050 & 0.217 \\
\hline $\begin{array}{l}\text { Immigrants in German households with Non } \\
\text { German passport }{ }^{1}\end{array}$ & 0.021 & 0.145 \\
\hline $\begin{array}{l}\text { Immigrants not in German households with } \\
\text { German passport }\end{array}$ & 0.068 & 0.252 \\
\hline $\begin{array}{l}\text { Immigrants not in German households with } \\
\text { Other passports }{ }^{1}\end{array}$ & 0.021 & 0.145 \\
\hline Feel totally discriminated ${ }^{1}$ & 0.013 & 0.111 \\
\hline Seldom feel discriminated ${ }^{1}$ & 0.063 & 0.242 \\
\hline Optimism and confidence about future & 0.582 & 0.493 \\
\hline Want to stay in Germany ${ }^{1}$ & 0.112 & 0.316 \\
\hline Financial worries & 0.150 & 0.357 \\
\hline Length of time with firm & 11.520 & 10.223 \\
\hline Treiman prestige score & 43.181 & 12.925 \\
\hline Regional Unemployment-Vacancies ratio & 5.556 & 2.749 \\
\hline Work in small company & 0.264 & 0.441 \\
\hline Work in large company & 0.457 & 0.498 \\
\hline Service, other industry & 0.126 & 0.331 \\
\hline Retail, wholesale, trade & 0.097 & 0.296 \\
\hline Government & 0.164 & 0.370 \\
\hline Manufacturing & 0.349 & 0.477 \\
\hline Construction & 0.117 & 0.321 \\
\hline Financial, Banking industry & 0.109 & 0.312 \\
\hline Agriculture, Mining, and missing (omitted) & 0.038 & 0.192 \\
\hline Weekly hours & 44.275 & 10.382 \\
\hline Weekly earnings & $1,279.588$ & 686.417 \\
\hline Predicted log earnings difference & -0.435 & 0.356 \\
\hline Number of observations & \multicolumn{2}{|c|}{5,509} \\
\hline Note: ${ }^{1}$ Pertains only to immigrants & & \\
\hline
\end{tabular}

